\title{
INVESTIGATING EARLY-CAREER TEACHERS' ADAPTATION CHALLENGES: A CASE OF INDONESIAN EFL TEACHERS
}

\author{
Yogi Saputra Mahmud ${ }^{1}$ \\ ${ }^{1}$ President University \\ ${ }^{1}$ yogi.saputra@president.ac.id
}

\begin{abstract}
Teacher professional development has recently become a central focus in the Indonesian context, particularly after the implementation of the post-bachelor teacher professional education program or Pendidikan Profesi Guru (PPG) for both pre-service and in-service EFL teachers in 2013. However, studies reveal that the transition from teacher education programs to the initial teaching career at schools has been described as a challenging phase. Despite the growing attention of scholars in exploring beginning teachers' challenges, studies focusing on the early-career Indonesian EFL teachers, particularly those who just completed the PPG program, are considered limited. Therefore, drawing on a qualitative case study with two beginning Indonesian secondary EFL teachers, this study aims to unravel the challenges during their first-year teaching experience at school after completing the PPG program. By thematically analysing the semi-structured interviews, this study indicated that the teachers experienced four significant challenges: 1) pedagogical (classroom management, lack of teaching resources, test-based learning atmosphere), 2) professional (complex self-identification), 3) social (maintaining rapport with senior teachers), and 4) personal (mood management). Despite having been trained professionally through the PPG program, the result suggested that the beginning teachers still faced considerable challenges during their initial endeavour as an English teacher at school. Pedagogical implications are discussed in terms of the need for continuous professional development for the newly certified teachers during their initial career at schools.
\end{abstract}

Keywords: Early-career teacher challenges, EFL, Pendidikan Profesi Guru (PPG), Continuous professional development

\section{INTRODUCTION}

The initial period of teaching experience can be either promising or challenging for early career teachers. According to Farrel (2012), early-career or novice teachers are characterised as teachers who have started teaching within three years after completing teacher education programs. During the initial period of teaching experience, beginning teachers are still in the process of adapting their expectations and knowledge gained from teacher education programs into a new professional community in their workplace (Veenman, 1984). This condition may result in some constraints that might be faced by early-career teachers at schools.

A number of studies have discussed the challenges faced by early-career teachers during their transition between teacher education programs and initial teaching experiences (Akcan, 2016; Amin \& Rahimi, 2018; Razmjoo \& Mavaddat, 2016; Salik \& Kecik, 2018; Widiati et al., 2018). Despite the growing attention to study the challenges faced by early-career English teachers, the number of studies that focus on the challenges faced by the Indonesian EFL teachers is still considered limited. At the same time, the teacher education program for pre-service teachers in Indonesia has experienced considerable reform through the implementation of a one-year post- 
bachelor teacher education program called Pendidikan Profesi Guru or Teacher Professional Education (TPE) program that will be explored in the following paragraph.

Since the beginning of 2013, a graduate of the Bachelor of Education degree is required to undertake the TPE program in order to be registered and certified as a professional English teacher (Afrianto, 2015). During this program, teacher candidates will join various pedagogical activities, including tutorials, lesson planning, development, and practice, teaching practicum, action research, and teacher competency tests (Kemenristekdikti, 2018). After successful completion of the program, the teacher candidates will be awarded an additional S.Pd. Gr. or Bachelor of Education (Teacher) degree as well as the certificate of professional English teachers that further certify them as guru profesional or professional teachers (Afrianto, 2015).

Although this program was implemented in 2013 for EFL teachers, there are only limited studies that explore the teachers' experience after completing this program and embarking their teaching career at school. Consequently, studies that focus on analysing the adaptation challenges faced by the Indonesian EFL teachers who have just completed the TPE program are still limited. Additionally, it is also argued that identifying early-career teachers' perceptions of their situation and their problems in their workplace may promote the reformation of activities and systems to enable and support their future career (Grenlee \& Dedeugd, 2002).

\section{Early-career EFL teachers in the Indonesian education system}

As stated in the previous section, a graduate of the Bachelor of Education degree is required to undertake the TPE program in order to be registered and certified as a professional English teacher (Afrianto, 2015). After completing the one-year program, the teacher candidates will be regarded as a professional teacher that is eligible to teach at a particular educational level. Besides the additional certification, teacher candidates who participate in the TPE program are expected to possess four teaching competencies that can be seen in the following figure:

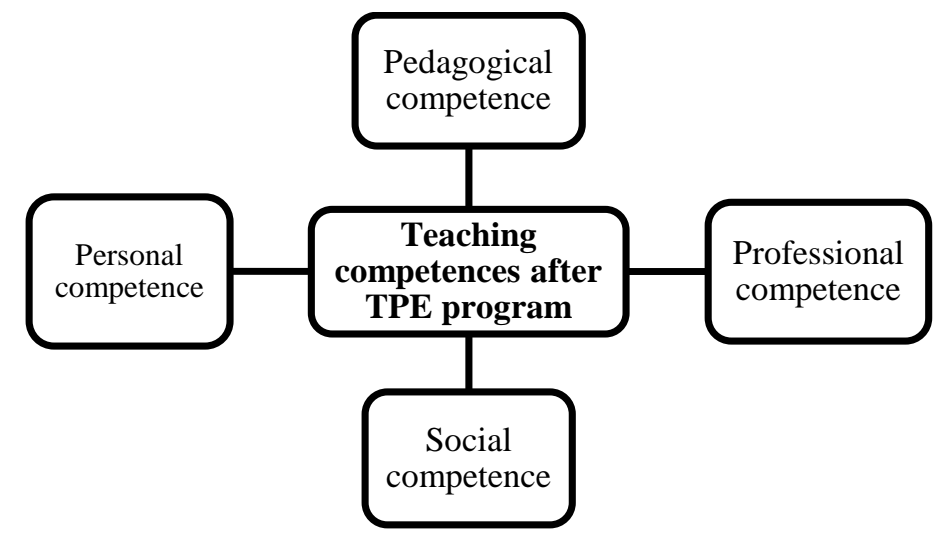

Figure 1. Teaching competences expected to be possessed by teachers after the TPE program (Kemenristekdikti, 2018).

Pedagogical competence refers to the ability to plan, conduct, and evaluate learning activities. This competence covers teachers' capacities in formulating, organising, and planning learning objectives, learning materials, lesson plans, conducting learning activities, as well as assessing/evaluating learning activities (Kemenristekdikti, 2018). Meanwhile, Personal competence deals with specific skills which shape the characteristics required to be a role model for students. In this case, this competence relates to a set of characteristics derived from social, 
ethical, cultural and legal norms in Indonesia (e.g. religion, nationhood, academic integrity, and others) that are essential for the teachers at their workplace (Kemenristekdikti, 2018). Social competence is associated with the ability to communicate and interact with, as well as to adapt to students, teachers, parents and society (Kemenristekdikti, 2018). Ultimately, professional competence refers to a set of competences in understanding learning concepts of being a teacher (Kemenristekdikti, 2018).

Although the TPE program for pre-service EFL teachers has been conducted for more than five years, studies that focus on analysing how the TPE program can address the challenges that might be faced by the early-career EFL teachers at school are still considered limited. Consequently, it is essential to investigate the difficulties faced by early-career teachers during their initial teaching trajectory. Concerning this, the expected teaching competences that have been discussed earlier can enact as a frame of reference to categorise the emerging problems.

\section{Studies in early-career teachers' difficulties}

Early-career teachers might face considerable constraints during their early involvement at schools. Consequently, it is argued that the initial step to address the problematic situations faced by novice teachers in teaching English is to elicit their voices/perceptions (Noughabi, 2017). Regarding this, several studies, for a long period, had been conducted to analyse the novice teachers' challenges at school. For instance, Veenman (1984) conducted a systematic literature review on perceived problems of beginning teachers at schools. In this case, his seminal work on this issue revealed that there are several problems perceived most by beginning teachers, including classroom discipline, students' motivation, relationships with parents, the burden of administrative work, inadequate teaching resources and guidance, as well as relationships with colleagues and principals.

Although Veenman (1984) study was conducted more than three decades ago, the result of the study is still echoed by various current studies (see Amin \& Rahimi, 2018; Gaikhorst et al., 2017; Razmjoo \& Mavaddat, 2016; Salik \& Kecik, 2018; Sarnou-Kenza Belatrech, 2018; Widiati et al., 2018). For instance, Salik and Kecik (2018) explored the challenges faced by seven novice EFL teachers in primary and secondary schools in Turkey. They further discovered that the teachers faced difficulties in classroom management, foreign language teaching-related difficulties, as well as school-context related difficulties (Salik \& Kecik, 2018). Meanwhile, Belatrech (2018) examined the challenges faced by 14 beginning EFL teachers in Algerian secondary schools. The author discovered that the teachers faced several difficulties, including pedagogical difficulties (lesson planning, the use of ICT, and others), social difficulties (maintaining rapport with students and colleagues), and classroom management difficulties.

In the Indonesian context, a study conducted by Widiati et al. (2018) focuses on scrutinising the difficulties faced by 11 English secondary teachers in terms of lesson planning and implementation, classroom management, and professional development with the focus of the 2013 curriculum implementation. However, this study does not address the adaptation challenges for EFL teachers who made their transition from teacher education programs to their initial teaching career.

According to the previous studies, there are several main difficulties faced by early-career EFL teachers around the globe, including classroom management, maintaining the relationship with other teachers, students, and parents, language-related difficulties, administrative/workload matter, and others. Moreover, these difficulties can be categorised further into the teaching 
competences suggested in the Indonesian system. For instance, the problems in lesson planning, classroom management, and other administrative difficulties can be categorised into pedagogical-related competence. Additionally, the difficulties in maintaining relationships with colleagues, students, and parents can be regarded as social-related difficulties. Meanwhile, the previous studies have yet to capture the professional and personal difficulties faced by earlycareer EFL teachers. Based on the previous studies, further, studies that explore difficulties faced by beginning Indonesian EFL teachers are still considered limited. Therefore, this study aims to fill in the gap of the literature by exploring the difficulties faced by early-career Indonesian EFL teachers, particularly those who participated in the newly established TPE program. To address the research objective, the research question is raised for exploration: "What adaptation challenges do the early-career Indonesian EFL teachers experience during their initial teaching career after completing the TPE program?”

\section{METHOD}

In terms of the research methodology, this study employed a qualitative case study which settled semi-structured interviews. According to Fraenkel and Wallen (2009), case studies involve systematic inquiries of particular social units; for example, one or a few individuals. In addition, case studies also emphasise the issues experienced by the individual/social units at the time of the research (Bhattacharya, 2017). Consequently, the current study aims to explore the adaptation challenges perceived by early-career Indonesian EFL teachers. In this case, it involved two research participants, Rita and Hani (pseudonyms), who had just embarked their initial teaching career after completing the TPE program. This research is mainly exploratory, which also emphasises description rather than measurement. Consequently, this research is more interested in exploring the stories described by each teacher regarding the difficulties faced by themselves as early-career teachers. The details of the participants in this study can be seen in Table 1.

Table 1. The research participants' information in the current research

\begin{tabular}{|c|c|c|c|c|}
\hline $\begin{array}{c}\text { Name } \\
\text { (Pseudonyms) }\end{array}$ & Age & $\begin{array}{c}\text { Teaching experience } \\
\text { (After completing } \\
\text { PPG program) }\end{array}$ & Teaching qualification & $\begin{array}{c}\text { Workplace/ } \\
\text { School }\end{array}$ \\
\hline Rita (Female) & 26 & $<1$ year & $\begin{array}{c}\text { S.Pd., Gr. (Bachelor of } \\
\text { Education - Teacher) }\end{array}$ & $\begin{array}{c}\text { Junior High } \\
\text { School (Public) }\end{array}$ \\
\hline Hani (Female) & 25 & $<1$ year & $\begin{array}{c}\text { S.Pd., Gr. (Bachelor of } \\
\text { Education - Teacher) }\end{array}$ & $\begin{array}{c}\text { Senior High } \\
\text { School (Private) }\end{array}$ \\
\hline
\end{tabular}

Purposeful sampling is one design strategy within qualitative research in which research participants were selected based on their ability to provide rich information about a phenomenon (Johnson \& Christensen, 2014). In this study, the participants were recruited purposively based on their involvement in the teacher education program, as well as their experience as beginning EFL teachers at secondary schools

\section{Data collection and analysis}

Interviews are utilised by qualitative researchers to explore the experiences of individuals and the way they interpret their worlds (Hatch, 2002). In relation to this, the current research employed semi-structured interviews to gather research data. Each participant was interviewed 
for approximately 40-60 minutes regarding three primary question themes: (a) the Bachelor of Education period (b) the Pendidikan Profesi Guru period, and (c) the initial teaching career period. Furthermore, some additional or probing questions were also asked to go more deeply into the areas of importance that emerged during the interviews. Additionally, the interviews were recorded in order to enable the researcher to fully concentrate on the interaction with the participants without hesitation or needing to pause to take notes.

The data analysis process was started by transcribing the interview recordings into text data. In order to maintain the internal validity, the researcher consulted with each research participant in clarifying the transcribed interview data. Furthermore, the data analysis process was continued to the coding process by breaking down segments of text data into smaller units and labelling the units based on the emerging themes from the data.

\section{Ethical consideration of the research}

The ethical considerations in this study began with the recruitment process by considering the participants' autonomy and independence to participate in this study. Throughout the recruitment process, potential participants were fully informed about the nature of the research. Ethical considerations were also applied in the data collection, analysis, and reporting phases, in which the researcher promoted openness and transparency to the research participants regarding data transcription and research findings. In this case, the participants were involved in checking the interview transcriptions to maintain data accuracy. Furthermore, the researcher also consulted with the participants to co-construct the participants' stories as parts of the research findings. At this point, the participants could extend or clarify their stories. This study also ensured the participants' anonymity by employing pseudonyms for names and other circumstantial attributes.

\section{RESULTS AND DISCUSSION}

\section{Results}

After analysing the transcribed interview data, it was revealed that the beginning Indonesian EFL teachers encountered several challenges during their early teaching career at school after completing the TPE program. These challenges include pedagogical, professional, social, and personal challenges that will be explored further below.

\section{PEDAGOGICAL CHALLENGES}

In terms of pedagogical challenges, it was discovered that the teachers experienced several difficulties: a. The conflict between the test-based atmosphere and personal belief in teaching English; b. Handling students with behavioural problems; and c. Lack of teaching resources and facilities.

\section{Test-based learning atmosphere}

The first pedagogical challenge relates to the heavily test-based learning atmosphere experienced by the teachers. In this case, both Rita and Hani perceived that there was a discrepancy between their personal beliefs in teaching English and the high pressure of accomplishing Ujian Nasional or National Examination at the end of the students' learning journey. This situation leads to the confusion experienced by the teachers, whether to emphasise the national examination or English skills. This can be seen in the following excerpt from Rita's interview: 
Sometimes I feel confused whether I should focus on the national examination or the English skills since they are not similar. I want the students to be able to communicate in English since the mastery of English is not determined by being able to do the written test like the National Examination, but rather by being able to communicate. (Rita).

Based on the excerpt above, it can be indicated that there is a conflicting issue between Rita's personal belief on the purpose of English language learning and her view on the National Examination. In another excerpt, Rita considers the National Examination as 'too theoretical' without emphasising on the students' ability to communicate in English.

Meanwhile, Hani elaborated that the challenges are related to the discrepancy between the materials being learned and being tested as illustrated in her excerpt below:

I think it is a bit useless because the materials being tested are different from what have learned. My students even asked: 'why should we learn when the materials being tested are different?' So it becomes a burden for myself and the students (Hani).

Despite the challenges faced by both teachers, they managed to alleviate the issues in different ways. For instance, Rita attempted to rebalance the focus on both improving English language skills and the National Examination by initiating the 'peer-tutor program' or 'buddy teacher.' Through the implementation of this program, Rita stated that the students would feel more thrilled to perform well in preparing the National Examination since the students would feel more responsible for each other.

Similarly, Hani also attempted to accommodate the targets of enhancing the students' English skills and their ability in answering the National Examination questions. In this case, she illustrated her agency in listening skills by focusing on familiarizing the students with expressions and pronunciations in the audio that might appear during the National Examination. At the same time, she also attempted to improve the students' listening skills by introducing the related audio in every different learning topic to make students feel more accustomed than before.

The pedagogical difficulties in rebalancing the focus between the national examination and English language skills experienced by Hani and Rita are also related to the study conducted by Sutari (2017). In this case, Sutari (2017) interviewed two teachers regarding their perceptions toward the national examination in the Indonesian EFL context. Based on the research, it was discovered that the teachers also faced dilemmatic teaching experiences when the teachers needed to focus on the national examination. Furthermore, this dilemmatic problem is also echoed by Akbari (2015) who outlined that when the learning activities are focused on preparing the students for doing examination rather than equipping them with linguistic skills, then the students will only focus on getting high grade without internalising their motivation to learn English. This condition further creates a problem for EFL teachers.

\section{Managing students with behavioural problems}

Besides experiencing challenges in rebalancing the focus between improving English language skills and accomplishing the National Examination, both teachers also faced difficulties in handling students with behavioural problems. Hani shared her concerns during her initial journey as an English teacher at her current workplace:

Many people know that the students in this school are naughty. When I entered the classroom for the first time, they were difficult to handle and acting 
carelessly. There were only a few who attended the class. Honestly, I was almost desperate with this situation. They also lack basic English skills, so I should be patient in teaching them. (Hani).

In the interview transcript, Hani elaborated her initial teaching experience at a private high school in the city of Bandung, West Java, Indonesia. Based on her explanation, the students in this school were perceived to have misbehaved characters. This situation leads Hani to experience pedagogical challenges in managing the students in the classroom. Furthermore, Hani also mentioned that she was 'almost desperate' with this circumstance, mainly when she realised that the students also lacked necessary English skills.

Meanwhile, Rita also experienced pedagogical challenges in terms of managing students' behaviour. In this case, she elaborated that it was challenging to handle the students 'who do not finish homework or assignments.' When facing this pedagogical challenge, Rita stated that there was a conflicting emotion between her internal feeling and her role as a teacher, in which she 'felt upset when students are unable to finish the assignments', while at the same time, she 'should not be upset due to mistakes committed by one or few students'.

Based on the interview with both participants, it could be indicated that both teachers made their efforts in resolving the pedagogical challenges they experienced during their initial teaching career. For instance, Rita resolved her problem by maintaining her internal feeling and emotion. In the case of Hani, the difficulty of managing the students' behaviour was perceived as a challenge to improve her ability in handling the students. In this case, she attempted to alter her internal perception toward the difficulties by challenging herself to make the students interested in learning the English lesson. There were also several strategies that she employed to achieve her desire in creating an engaging learning atmosphere for the students, including the use of music and rewards in the learning process.

The difficulty of managing students are also reported in other studies, including a study conducted by Amin and Rahimi (2018). In this case, the researchers surveyed 20 beginning EFL teachers in Iraq regarding the teachers' difficulties during their initial career. The researchers further discovered that half of the teachers faced difficulties in preparing effective strategies to handle the students with behavioural problems. In another study conducted by Salik and Kecik (2018) who explored the difficulties faced by early-career Turkish EFL teachers also revealed that the teachers faced challenges in establishing rapport with the students. In this case, the challenges further negatively influenced the teachers to feel not confident when they faced students with disruptive behaviour (Salik \& Kecik, 2018).

\section{Lack of teaching resources}

Limited teaching resources and facilities become another pedagogical concern raised by the teachers, particularly Hani. In this case, Hani considered her current workplace, a private high school in Bandung, as lack of teaching and learning facilities. For instance, she suggested that 'overhead projectors are not available' during her initial teaching career. In relation to the learning resources, Hani described that the school also lacks learning materials and textbooks. Consequently, the school instructed the English teachers to utilise Lembar Kerja Siswa or Student's Worksheet. This situation led Hani to feel 'shocked' when she encountered the fact that the school only depended on the student's worksheet.

Despite the challenges experienced by Hani, she attempted to overcome the lack of teaching materials by employing several strategies, including developing learning materials from the 
internet and adapting the materials with the students' needs and characteristics. Without the overhead projector, Ani depended on the audio system in providing the linguistic input for the students.

The inadequacy of teaching materials is also discovered in several studies conducted in the EFL context (see Grenlee \& Dedeugd, 2002; Salik \& Kecik, 2018). In this case, Grenlee and Dedeugd (2002) clarify that beginning teachers often feel shocked when they have inadequate teaching materials and resources to equip their teaching performance. Meanwhile, in a study conducted by Salik and Kecik (2018), six of seven research participants argued that they faced difficulties in managing teaching materials since the schools lacked in various instructional materials. Furthermore, the inadequate instructional materials also influenced negatively on the teaching activities conducted by the teachers (Salik \& Kecik, 2018).

\section{PROFESSIONAL CHALLENGES}

Besides the pedagogical challenges, the beginning teachers also encountered conflicting internal perception after obtaining the additional qualification as a professional English teacher through their involvement at the TPE program. In addition, the teachers also faced challenges in managing multiple responsibilities during their initial teaching career at school.

\section{Complex self-identification of becoming an early-career teacher}

Before embarking the teaching career, both teachers participated in a post-bachelor teacher education program named TPE program that led themselves to obtain an additional title of Guru Profesional (SPd. Gr.) or Professional Teacher. Despite this additional qualification, it was indicated that the teachers experienced complex dispute between identifying themselves as both early career yet professionally trained and qualified English teachers. Rita expressed her concern related to this:

\section{After obtaining this degree, I think it gives me another burden but eventually, it becomes additional motivation and responsibility. I feel like I have a greater responsibility than those who only have S.Pd. degree in administration and classroom management (Rita).}

In this case, Rita perceived the additional qualification as a burden since it pushed herself to perform better than those who did not participate in the TPE program. Despite this, Rita changed her perspective from 'burden' to an 'additional motivation and responsibility' particularly in terms of preparing teaching administration and managing the classroom.

In a similar vein, Hani also raised her concern regarding the complex self-identification process during her initial career as an English teacher. Regarding this, Hani suggested that her involvement at the TPE program led others to have high expectations that she would be 'able to teach skillfully.' At the same time, she asserted that she had 'just graduated from the bachelor's degree,' in which she still lacks experience in teaching. After obtaining the additional qualification, further, Hani stated that she needed to prove to others that she was able to put greater effort than those who did not possess the additional qualification particularly in terms of planning and delivering the lesson.

Based on the findings above, both teachers experienced the complexities of their professional identity development as beginning English teachers, but they had already participated in the TPE program that certified themselves as professional teachers. Consequently, it gives an 
additional challenge for themselves to fulfil the expectations of other teachers towards both Hani and Rita.

\section{SOCIAL CHALLENGES}

Based on the interview, both participants suggested that maintaining the relationship with senior teachers was also perceived as a challenge during their early teaching career. Hani elaborated her experience when a senior English teacher, Mrs Anna (pseudonym), confronted her during her early teaching career. In this case, Hani suspected that Mrs Anna was 'upset' since Hani taught more classes than Mrs Anna. Moreover, Hani stated that Mrs Anna often commented that Hani 'was still incompetent and inexperienced to teach.' Additionally, Hani elaborated that Mrs Anna often criticised the way Hani delivered learning activities and handed out assignments to the students:

Theoretically, there are four competencies that should be possessed by a PPG graduate, including social competency. We should be able to maintain our relationship with students, teachers, parents, and other school employees. In reality, there is a gap between honorary teachers and senior teachers (Rita).

Regarding this, Hani also attempted to reflect on what Mrs Anna did in her class. In this case, she perceived that Mrs Anna's strategy was considered ineffective for an English project. Furthermore, Hani also offered several strategies to incorporate multimodal media in the project. Meanwhile, Rita also experienced social challenges in maintaining a relationship with senior teachers:

When I asked the students to do some tasks or projects, Mrs Anna always monitored and criticised: 'This is wrong'. But I think what she did in her class was also incorrect. Asking the students to create a scrapbook is not effective for a project since they only copy what is written in the book. We can involve other things in creating a project, such as drama or song. But I still appreciate her as a senior (Hani).

In this case, Rita expressed that there was a gap between her, as a non-permanent teacher, and the senior teachers. Rita acknowledged that she felt inferior among the senior teachers though she was professionally trained and accredited as a professional teacher. Regarding this, she also attempted to internalise her experience in facing the social challenge towards her involvement at the TPE program.

A study conducted by Salik and Kecik (2018) also revealed that beginning EFL teachers also faced social difficulties during the initial teaching career. In this case, the researchers discovered that several participants (EFL teachers in Turkey) were lacking collegial support from senior teachers during their initial teaching career. Meanwhile, Widiati et al. (2018) who explored the challenges faced by Indonesian novice EFL teachers, also discovered that the teachers did not have any mentor teachers during their early teaching career. Consequently, most of the research participants were also unable to consult or discuss problems related to their teaching activities at the school (Widiati et al., 2018).

\section{PERSONAL CHALLENGES}

In addition to the three challenges above, both teachers also perceived that they experienced personal challenges in terms of mood management when handling students with behavioural problems. For instance, Rita asserted that her personality as an introvert person debilitated her 
role as a teacher that required herself to interact with many people. In Hani's case, she perceived that she faced difficulties in maintaining a friendly personality with the students:

They often refer me as a grumpy teacher, but I did not feel that I am that grumpy. I think it is because of my role as a Wakasek Kesiswaan who often warn disobedient students, so the students think that I am a Wakasek Kesiswaan even in the classroom (Hani).

Regarding this, she argued that her role as a staff of Vice-Principal for students' affairs led the students to perceive that she was unfriendly even when she was teaching in the classroom. The discussion of personality traits of becoming a teacher is also outlined by Jalili and Amiri (2015) who argued that factors such as personality types of a teacher should become a concern for teachers to manage teaching activities with a satisfactory result. Furthermore, the researchers also discussed the needs of mentors or senior teachers' guidance for early-career teachers who might have personal challenges in maintaining their personality traits during teaching activities (Jalili \& Amiri, 2015).

\section{CONCLUSION}

In conclusion, there were four significant challenges faced by the early-career EFL teachers during their transition from the completion of the TPE program and their initial career as EFL teachers at schools. Firstly, the teachers argued that they faced pedagogical challenges in the form of test-based learning atmosphere, managing students with behavioural problems, as well as lack of teaching resources. Secondly, they also experienced the complexities of their identity as beginning yet professionally trained teachers. Thirdly, maintaining relationship with senior teachers also became a considerable social challenge faced by the teachers during their early teaching career. Ultimately, the teachers also mentioned their difficulties in managing their mood and personal feelings when dealing with misbehaved students at schools.

Several limitations are evident in this study, including the sample size and methodology. First, this study involved a small sample of English teachers who had just embarked their teaching experience after completing the Teacher Professional Education program or Pendidikan Profesi Guru. Furthermore, the study only involved female teachers; consequently, it cannot explore how gender contributes to teacher development and the strategies to cope with the problems at school. Second, this study only covered the participants' initial teaching experience using one data collection method Despite the contribution that a qualitative interview can offer, the use of multiple data collection methods (e.g., reflective journals, longitudinal research, etc.) would enrich and deepen the analysis of the study.

Based on the findings and limitations of the study, there are several implications and recommendations proposed by the study. In terms of practice, it is essential to provide additional and on-going professional development for early-career English teachers despite having been trained through the PPG program. Furthermore, it is also strongly encouraged for the PPG program to discuss possible challenges that might be encountered by beginning teachers at their future workplaces. In relation to future studies, researchers may focus on the learning experience of teacher candidates during the PPG program in relation to teaching preparedness. In addition, researchers may also delve into the impact of PPG program toward the teachers' preparedness and confidence in teaching. The use of multimodal data collection tools (e.g. field notes, reflective journals, etc.) is particularly encouraged. 


\section{ACKNOWLEDGMENTS}

This work was supported by the Indonesian Endowment Fund for Education (LPDP) for the process of collecting and analysing research data. Also, the author would like to acknowledge the contribution of Faculty of Education, Monash University for the funding of the paper presentation at the International Graduate Research Symposium 2019 in Hanoi, Vietnam. Any opinions, findings, and conclusions or recommendations expressed in this material are those of the author and do not necessarily reflect the views of related parties.

\section{REFERENCES}

Afrianto, A. (2015). Constructing professional identity through teaching practicum: An Indonesian case study of pre-service English teachers [Monash University]. https://monash.figshare.com/

Akbari, Z. (2015). Current Challenges in Teaching/Learning English for EFL Learners: The Case of Junior High School and High School. Procedia - Social and Behavioral Sciences, 199, 394-401. https://doi.org/10.1016/j.sbspro.2015.07.524

Akcan, S. (2016). Novice non-native English teachers' reflections on their education programmes and their first year of teaching. Profile, 18(1), 55-70. https://doi.org/10.15446/profile.v18n1.48608

Amin, M. Y. M., \& Rahimi, A. (2018). Challenges faced by novice EFL teachers. International Journal of Humanities and Cultural Studies, 5(1), 149-166. http://www.ijhcs.com/index.php/ijhcs/index

Belatrech, H. S.-K. (2018). Novice EFL Teachers' Challenges in Mostaganem Rural Areas. Social Sciences, 7(3), 125-132. https://doi.org/10.11648/j.ss.20180703.13

Bhattacharya, K. (2017). Fundamentals of qualitative research: A practical guide. Routledge.

Farrel, T. S. C. (2012). Novice-service language teacher development: Bridging the gap between preservice and in-service education and development. TESOL Quarterly, 46(3), 435-449. https://doi.org/10.1002/tesq.36

Fraenkel, J. R., \& Wallen, N. E. (2009). How to design and evaluate research in education (7th ed.). McGraw-Hill.

Gaikhorst, L., Beishuizen, J., Roosenboom, B., \& Volman, M. (2017). The challenges of beginning teachers in urban primary schools. European Journal of Teacher Education, 40(1), 46-61. https://doi.org/10.1080/02619768.2016.1251900

Grenlee, B. J., \& Dedeugd, I. S. (2002). From hope to despair: The need for beginning teacher advocacy. Teacher Development, 6(1), 63-74. https://doi.org/10.1080/13664530200200157

Hatch, J. A. (2002). Doing qualitative research in education settings. State University of New York Press.

Jalili, S., \& Amiri, B. M. (2015). The difference between extrovert and introvert EFL teachers' classroom management. Theory and Practice in Language Studies, 5(4), 826-836. http://dx.doi.org/10.17507/tpls.0504.19

Johnson, B., \& Christensen, L. B. (2014). Educational research: Quantitative, qualitative, and mixed approaches. Sage Publications.

Kemenristekdikti. (2018). Pedoman penyelenggaraan program pendidikan profesi guru.

Noughabi, M. A. (2017). Current pedagogical challenges in Iranian EFL teachers' views: A qualitative study. Journal of Education and Practice, 8(9), 217-228.

Razmjoo, S. A., \& Mavaddat, R. (2016). Understanding professional challenges faced by Iranian teachers of English. International Journal of English Linguistics, 6(3), 208-220. https://doi.org/10.5539/ijel.v6n3p208 
Salik, P., \& Kecik, I. (2018). Challenges of first years of teaching in Turkey: Voices of novice EFL teachers. English Language Teaching, 11(4), 117-131. https://doi.org/10.5539/elt.v11n4p117

Sutari, V. R. (2017). National examination in Indonesia and its backwash effects: Teachers' perspectives. The Ninth International Conference on Applied Linguistics (CONAPLIN 9), 331-333.

Veenman, S. (1984). Perceived Problems of Beginning Teachers. In Review of Educational Research (Vol. 54, Issue 2). https://doi.org/10.3102/00346543054002143

Widiati, U., Suryati, N., \& Hayati, N. (2018). Unraveling the challenges of Indonesian novice teachers of English. Indonesian Journal of Applied Linguistics, 7(3), 621-629. https://doi.org/10.17509/ijal.v7i3.9824 